\title{
Identifying Hotspots in the Carbon Footprint of a Small Scale
}

\section{Organic Vegetable Farm}

\author{
${ }^{1}$ Cornelius Adewale, ${ }^{2}$ Stewart Higgins, ${ }^{3}$ David Granatstein, ${ }^{4}$ Claudio O. Stöckle, ${ }^{4}$ Bryan R. \\ Carlson, ${ }^{5}$ Usama E. Zaher, ${ }^{1,2}$ Lynne Carpenter-Boggs
}

1. School of the Environment, Washington State University (WSU); 2. Dept. Crop \& Soil

Sciences, WSU; 3. Tree Fruit Research \& Extension Center, WSU; 4. Dept. Biological Systems

Engineering, WSU; 5. INTERA Inc.

\begin{abstract}
Despite its potential to mitigate many environmental impacts of agriculture, organic farming does contribute to greenhouse gas (GHG) emissions. A full accounting and understanding of the GHG emissions associated with specific activities, materials, and energy used in organic operations is needed to support decision-making for GHG mitigation. A small-scale organic vegetable farm in Washington State, USA, was used as a case study to determine the carbon footprint (CF) and GHG hotspots. A partial life cycle assessment was conducted to identify primary and secondary GHG fluxes associated with activities and materials used in production of potatoes, cauliflower, dry bush beans, winter squash, summer squash, chard, peppers, and onions grown in a crop rotation. The CF associated with each crop ranged from a low of $1.68 \mathrm{t}$ $\mathrm{CO}_{2}$-eq ha ${ }^{-1} \mathrm{yr}^{-1}$ for chard to a high of $2.67 \mathrm{t} \mathrm{CO}_{2}$-eq ha ${ }^{-1} \mathrm{yr}^{-1}$ for cauliflower. Cauliflower had the highest CF per ha followed by potatoes and pepper. Across the farm as a whole, the major CF
\end{abstract}


hotspots were fuel use for both on-farm and off-farm operations (38\%), fertilization (18\%), soil emission (12\%), and irrigation (11\%). Simulation of a switch to biodiesel instead of petroleum gasoline and diesel resulted in a $32 \%$ reduction in the total farm CF. By identifying the CF hotspots of a whole farm and individual crops, particular inputs and activities can be targeted for modification in order to effectively reduce the farm's CF.

\section{Keywords}

Carbon footprint, vegetable production, organic farming, GHG emissions

\section{Introduction}

The natural cycles of carbon and nitrogen have been disrupted in many ways by human activities in the past two centuries. Human activities responsible for this disruption include the world-wide conversion of native prairies to agriculture, burning of fossil fuels, deforestation, and industrial $\mathrm{N}$ fixation by the Haber-Bosch process. The net effect of these actions is an increase in the concentration of atmospheric $\mathrm{CO}_{2}$ from around $280 \mathrm{ppm}$ just prior to the industrial revolution to more than $400 \mathrm{ppm}$ today and that of $\mathrm{N}_{2} \mathrm{O}$ from $275 \mathrm{ppb}$ to more than 324 within same timeframe (Prather et al., 1995; IPCC, 2007; Monastersky, 2013).

The continual increase of $\mathrm{CO}_{2}$ and other greenhouse gas (GHG) concentrations in the atmosphere is the major driver of global climate change, a phenomenon that has been described as one of the greatest environmental challenges threatening the sustainability of humankind and natural ecosystems (Millennium Ecosystem Assessment, 2005). IPCC (2014) reported that about $25 \%$ of the total global annual emissions of $\mathrm{CO}_{2}$ can be attributed to agriculture, forestry, and other land use. Agriculture is also the largest source of anthropogenic 
$\mathrm{N}_{2} \mathrm{O}$ and the second largest source of $\mathrm{CH}_{4}$ in the United States, accounting for almost $80 \%$ and $30 \%$ of these emissions, respectively (Snyder and Bruulsema, 2007; Snyder et al., 2009; EPA, 2008). Agricultural activities contribute about $20 \%$ of the global radiative forcing (GRF) (Lal et al., 1999). Agricultural systems' GHG emissions come from diverse sources such as $\mathrm{N}_{2} \mathrm{O}$ emissions from agricultural soils, $\mathrm{CH}_{4}$ emissions from livestock enteric fermentation, manure management, rice paddies, machinery manufacture and maintenance, transport of materials, and the manufacture of crop protection chemicals and fertilizers.

Effective mitigation of global climate change from the agricultural sector will require an understanding of the net GHG emissions that are associated with activities, materials and energy used in farming operations and an understanding of the potential cost-effective reductions in emissions (Dick et al., 2008; Moxey, 2008). The calculation of the carbon footprint (CF) of farms and farm products can contribute to this understanding. A CF calculation identifies the quantity, sources and sinks of GHGs associated with on-farm and off-farm activities (depending on the boundary of the system chosen) with the goal of identifying opportunities to reduce GHG emissions and increase GHG sinks in the system. Carbon footprints are expressed in units of $\mathrm{CO}_{2}$-equivalent emissions $\left(\mathrm{CO}_{2}\right.$-eq), with $\mathrm{GHG}$ other than $\mathrm{CO}_{2}$ expressed in terms of their GWP relative to $\mathrm{CO}_{2}$ (Lynas, 2007; Wiedmann and Minx, 2008). Agriculture is not only a source of GHG, but can act as a sink for C by increasing stored soil organic carbon (SOC). Estimated global SOC sequestration potentials range from 0.2 to $1.87 \mathrm{Pg}$

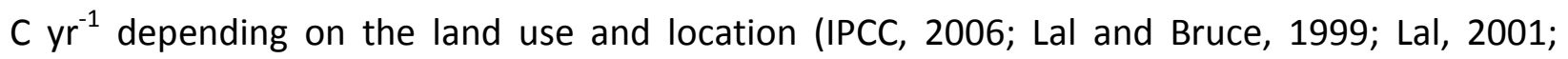
Conant et al., 2001). Although the potential of SOC sequestration is finite (Lal, 2004b) it has the 
potential to offset 5 to 15\% of the global fossil-fuel emission (Kauppi and Jedjo, 2001; Lal, 2004a; Lal, 2004b).

Several studies have found organically managed soils to have greater soil $\mathrm{C}$ than those managed under conventional farming systems (Marriott and Wander, 2006; Gattinger et al., 2012; Leithold et al., 2015). Additional GHG mitigation potential from organic farms comes from growing legumes to supply $\mathrm{N}$, and lower external inputs of fertilizers and agrochemicals. Scialabba and Müller-Lindenlauf (2010) reported that abstention from industrially produced $\mathrm{N}$ fertilizers by organic agriculture could reduce total global GHG emissions by about $20 \%$. They also suggested that potential $\mathrm{C}$ sequestration by organic farming could compensate for $40-72 \%$ of the world's current annual agricultural GHG emissions.

Although many aspects of organic farming have potential to mitigate GHG emissions, organic farms nevertheless emit GHGs both directly and indirectly. Increased cultivation or specialized materials for weed, disease and pest management may result in greater GHG impacts than a synthetic agrichemical based system, depending on how the system is evaluated (Kotschi and Müller-Sämann, 2004; Pimentel, 2006). Transportation of organic feeds and bulky inputs also contribute to potentially greater GHG emissions in organic systems (Wood et al., 2006; Meisterling et al., 2009).

Several authors have presented the need for Life Cycle Assessment (LCA) of agricultural systems and food products (Andersson et al., 1994; De Boer, 2003; Foster et al., 2006). However, few studies have examined the CF of organic vegetable production in the United States. Previous studies on the CF of organic vegetable production focused on comparing the CF 
of the organic systems with conventional farming systems (Cederberg and Mattsson, 2000; Hillier et al., 2009). Also, none of the previous CF studies accounted for soil emissions attributable to organic vegetable production.

Using a case study approach, we analyzed the CF of a small ( $0.81 \mathrm{ha}$ ) organic vegetable farm in western Washington State. The main goal of the study was to identify those activities, materials, and inputs that contributed most to the CF of vegetable production and to compare the CF associated with different vegetables in the rotation. A partial LCA (PLCA), cradle to farm gate, (Monti et al., 2009) was used to determine the emission factors for all important primary and secondary GHG sources and sinks associated with farm management. Primary emissions here are defined as those from the farm or production system during the actual production process. Secondary emissions are those that occur during the manufacture or production of resources used in the production system. The soil dynamics as a source or sink of GHG emissions were assessed with CropSyst, a cropping systems simulation model (Stöckle et al., 1994; 2003). CropSyst simulates the effect of site-specific climate, soils, and management on soil-plant-atmosphere water and $\mathrm{N}$ dynamics, canopy and root growth, biomass production, crop yield, residue production and decomposition, and soil erosion by water to create estimates of $\mathrm{N}$ and $\mathrm{C}$ fluxes to atmosphere, leaching and balances in soil. The model requires information inputs including crop phenology, canopy coverage, root depth, residue decomposition characteristics, weather, soil characteristics, and cropping system management options including crop rotation, $\mathrm{N}$ fertilization, tillage operations, and residue management. 
The specific objectives were to: (1) establish an inventory for CF analysis of organic vegetable production, (2) assess the CF of the farm and each crop produced, and (3) identify GHG emission hotspots in the life cycle of the farm and each crop that might be reduced by management changes.

\section{Materials and Methods}

\subsection{Study site and design}

A cradle to farm gate PLCA and simulation of crop and soil dynamics were conducted to estimate the GHG fluxes within the farm. The GWP was estimated by considering the $\mathrm{CO}_{2}, \mathrm{CH}_{4}$ and $\mathrm{N}_{2} \mathrm{O}$ emissions associated with energy and material inputs, activities, and crop and soil dynamics during the production chain. The net GHG emission was determined as the difference between the $\mathrm{CO}_{2}$-eq emitted and $\mathrm{CO}_{2}$-eq sequestered across the life cycle of the crops produced on the studied farm, using IPCC methodology and $\mathrm{CO}_{2}$-eq emissions factors (Nemecek and Kägi, 2007; IPCC 2007).

The study site was a 0.81 ha vegetable production area on an organic farm (certified by Washington State Department of Agriculture) located near Ridgefield, Washington, USA $\left(45^{\circ}\right.$ $45^{\prime} 45^{\prime \prime} \mathrm{N}, 122^{\circ} 43^{\prime} 5^{\prime \prime} \mathrm{W}$ ). The soil on the farm was predominantly Hillsboro silt loam, (finesilty, mixed, superactive, mesic Typic Glossudalfs) (Soil Survey Staff). The climate was typical of the maritime region, with cool, wet winters, and moderately warm, dry summers. In addition to being certified organic, the farm was selected because: (1) it was representative of small-scale vegetable production in the Pacific Northwest with diverse annual and perennial crops (Ostrom 
and Donovan, 2013); and (2) detailed records required to carry out the PLCA of the farm were available from the producer.

Since our primary purpose was to calculate the CF of organic vegetable production, GWP (kg $\mathrm{CO}_{2}$-eq on a 100 -year time scale) was the impact category for this study. Normalized CF of typical inputs to organic agriculture (Table S.1) used in this study were based on emission factors recommended by the IPCC (2007) and Nemecek and Kägi (2007). Output units for the whole-farm CF were $\mathrm{kg} \mathrm{CO}_{2}$-eq ha ${ }^{-1} \mathrm{yr}^{-1}$ or $\mathrm{kg} \mathrm{CO}_{2}$-eq farm $\mathrm{yr}^{-1}$. The output units used for each crop CF were primarily $\mathrm{kg} \mathrm{CO}_{2}$-eq $\mathrm{ha}^{-1} \mathrm{yr}^{-1}$, but depending on objectives, were converted to $\mathrm{kg}$ $\mathrm{CO}_{2}$-eq $\mathrm{kg}$ dry yield ${ }^{-1} \mathrm{yr}^{-1}$ or $\mathrm{CO}_{2}$-eq $\mathrm{kg}$ fresh yield ${ }^{-1} \mathrm{yr}^{-1}$. The functional unit (FU) refers to the main function of the system analyzed and is the reference unit for the inputs and outputs of the system analyzed. Since the final function was the production of vegetables, the FU chosen for this study was the mass unit (1 metric tonne of fresh organic vegetables) produced in 2012.

For further analysis of potential methods to reduce the CF hotspots of the farm, hypothetical simulations used biodiesel instead of petroleum gasoline and diesel, and used solar powered irrigation in place of the current hydroelectric powered irrigation while other factors were held constant. This simulation was effected without CropSyst since the two factors changed have no effect on soil dynamics.

\subsection{Partial Life Cycle Assessment}


The system boundary contained the processes and inputs required for the entire farm production system and performance of farm operations until the farm products (vegetables) left the farm gate. We evaluated all flows that contributed to the embodied CF of the input delivered to the farm gate including extraction of raw materials (cradle), manufacturing/production processes and transportation. The embodied energy of each item was determined using the energy coefficients as indicated in Table S.1. The CF of all farm machinery was calculated from the embodied energy of the raw materials, fabrication energy, an allowance for repairs and maintenance, and freight to get the machinery to the farm. The larger the machine the greater the associated embodied emissions. Also, the more often a machine is used for a given crop the more of this emission will be attributed to the crop making use of it. Indirect $\mathrm{CO}_{2}$-eq emissions of each item of infrastructure or equipment were allocated annually based on the average working life of the item and usage by each crop (Wells, 2001). The CF of these inputs also included their end-of-life disposal (grave) when appropriate, e.g., recycling of drip tape, or landfill burial of spent hoop house plastics. Therefore, for many inputs, the CF boundary was cradle-to-grave. However, for some inputs that included waste materials as feedstocks, the concept of cradle was different. For example, the chicken manure used as a feedstock for compost was a waste product of chicken production and was considered to have no embedded CF since the CF was allocated to the chicken farm from whence the manure came. But, the transportation of the manure to the composting facility, the compost production process (turning, aerating, packaging, etc.) and transportation to the organic farm all contributed to the CF of the chicken manure compost as used on the farm. Therefore, the CF analysis of inputs was essentially cradle to grave. 
The project boundary enclosed the property owned by the farmer. On-farm buildings, energy, and other inputs were within the project boundary only if they directly supported crop production prior to the crop leaving the farm gate, e.g., greenhouses and high tunnels. Residences, domestic outbuildings, and domestic energy use were excluded from the project boundary. Input units used were generally as-delivered to the farm, e.g., kg compost (asdelivered, not dry-weight equivalent), $\mathrm{kg}$ of tractor (in operating condition), $\mathrm{m}^{3}$ of water, $\mathrm{kWh}$ of electrical power, etc. These units were converted to $\mathrm{kg} \mathrm{CO}_{2}$-eq.

\subsection{Farm Inventory development}

The farm operation inventory included all materials and resources used in the process of production. The inventory provided the basis for the calculation of both the direct and indirect GHG emissions associated with the production of each crop grown. Data on farm inputs, activities, and infrastructure were collected through personal interviews with the farmer, examination of records kept by the farmer, and direct observation and inspection of the farm (Table 1, 2 and 3). The inventory analysis was divided into 4 main segments: (1) farm operations (2) soil and crop inventory dynamics (3) energy inputs and (4) farm facilities (Fig 1).

The organic vegetable production area consisted of 9 contiguous plots of $891 \mathrm{~m}^{2}$ per plot. Individual plot management followed a 10 year rotation of cash crops and cover crops as indicated in Table 1. Each plot had 12 beds of $60 \mathrm{~m}^{2}$ plus paths for foot and wheel traffic between beds. Two plastic drip tapes were installed on each bed. The GHG emissions embedded in materials and equipment, and energy consumed in their use were allocated to each crop based on usage through PLCA. The energy and resources for maintenance of the farm 
implements and transportation of the materials were also considered. Equipment lifespans were estimated by the producer.

\subsection{Crop and Soil Dynamics}

\subsubsection{CropSyst parameterization for the study}

Basic soil characteristics for the site were obtained from STATSGO2 (Soil Survey Staff). The CropSyst soil profile initialization was based on soil samples collected at representative locations on the farm at $0-30 \mathrm{~cm}$ (Table S.2). These samples were analyzed at Soil Test Farm Consultants, Moses Lake, WA. Initial soil characteristics for layers below the sampling depth of $30 \mathrm{~cm}$ were based on knowledge of how these soil parameters ordinarily behave. The temperature and precipitation data used to drive CropSyst were collected from the National Climatic Data Center (NOAA). Other weather elements were derived from the Bureau of Reclamation's AgriMet database with missing data estimated using ClimGen (Castellvi and Stöckle, 2001). When complete, the CropSyst weather data file contained continuous weather data from 1970 through 2008.

The crops modeled in this study were generalized to the extent reasonable by setting as many of the crop parameters as possible to common values (Table S.3). Many other crop parameters were set to values suggested by accounts in the literature. Table S.4 presents some $\mathrm{N}$-dynamics crop parameters based on the literature. Table S.5 presents crop harvest indices and canopy coverages. Once these crop parameters were set, CropSyst was calibrated by adjusting 
appropriate parameters to obtain yield estimates that were within $10 \%$ of published values (Table S.6) for these crops when grown under conventional conditions. The rye/vetch cover crop was an exception to this $10 \%$ goal; its simulated production exceeded published accounts by $14 \%$ for the winter cover crop (Lawson et al., 2013) and by $19 \%$ for the 1-year cover crop (Leavitt et al., 2011). Two potential explanations for the overestimates were that 1) the mixture was treated as a $\mathrm{N}$ fixer even though only the vetch portion of the mixture was a $\mathrm{N}$ fixer, and 2) the same crop file was used for both the 1-year and the winter-only durations of this cover crop. It was difficult to reconcile these two seasons using a common crop file.

Once crops were well-simulated under conventional conditions, organic management conditions were imposed by first turning off the automatic $\mathrm{N}$-fertilizer option in CropSyst and then applying organic fertilizers according to the type, rate and schedule reported by the farmer (Table 1). The reduction in yield for simulated organic crops was consistent with published accounts (de Ponti et al., 2012). Predicted yield was greater than farmer reported yield for 6 of the 8 crops. Cropsyst makes no adjustment for crop losses to pests or unsaleable produce. We assumed that many of the discrepancies between CropSyst's predicted yields and those reported by the farmer were due to such losses. We therefore adjusted the harvest index down for the respective crops to match the farmer's reported yield. This downward adjustment of the harvest index had the effect of assigning a greater proportion of the aboveground biomass to the residue $\mathrm{C}$ pool.

A 4-year preconditioning term preceded the 30-year model run reported here. This preconditioning period allowed CropSyst to stabilize initial conditions. 


\subsubsection{CropSyst Simulation for Soil Dynamics}

The contributions of crop and soil dynamics to the total CF of the farm were modeled with CropSyst (Stöckle et al., 1994, 2003, 2012). Estimated impacts included net change in SOC, annual soil $\mathrm{N}_{2} \mathrm{O}$ emission, and $\mathrm{N}$ leached. Details of CropSyst parameterization are provided in supplementary data (Tables S.2, S.3, and S.4). The scenario was run for 30 years so that the production of each crop was simulated in each year of the weather file. The entire series of simulations was then repeated twice to assess the impact of the cover crops on the farm's CF. The first repetition excluded all cover crops except the rye/vetch cover crop that grew for 1 year (Table 1). The final repetition excluded all cover crops. For the simulation, each operation was conducted on the calendar date provided by the farmer with two exceptions. First, when multiple harvests of a single crop were reported by the farmer only the last harvest date was simulated for cash crops. Second, for those crops that were irrigated, CropSyst was programmed to start automatically irrigating at the time of seeding or transplanting and end on the date the farmer stopped irrigating. There were some instances in which more than one crop was, in reality, planted on the same plot. In this situation, the predominant crop was used for the simulation. Cropsyst lacked the capacity to simulate the growth of more than one crop simultaneously. Therefore we were unable to mimic such management strategies as companion planting and underseeding even though these were practices employed by the farmer. All simulated biomass production resulted from crop growth with the exception of crimson clover (see below). 
The equipment and management options used by the farmer were matched as closely as possible to options in the PLCA and simulated by the management files in Cropsyst. The farm management options and fertilizers used are listed in Table 1.

\section{Results and Discussion}

\subsection{Hotspots in the carbon footprint of farm operations}

Within the field boundary of the farm, the materials and operations used in tillage, fertilization, and irrigation were the highest contributors to the CF of farm operations with CF of 3,609 (31.6\%), 3,333 (29.2\%), and 2,088 $\mathrm{kg} \mathrm{CO}_{2}$-eq ha $\mathrm{hr}^{-1}(18.3 \%)$, respectively (Table 4). Tillage included disking and rototilling, but disking alone was responsible for $26.7 \%$ of the CF of field operations. Most of the tillage CF was due to fuel use. Fertilization included the production and field application of an organic fertilizer blend and bonemeal. Most of the fertilization CF was due to the fertilizer production, but field equipment use for fertilizer application also contributed. Pumping of irrigation water with the $7.5 \mathrm{hp}$ pump was the largest single user of onfarm energy in the studied case. This corroborates previous studies in which electricity consumption was identified as a major contributor of indirect GHG emission for the vegetable industry (O'Halloran et al., 2008; Saunders and Barber, 2008). The mobile hoop house for 
pepper production and row cover (Reemay $\left.{ }^{\circledR}\right)$ for cauliflower were also meaningful contributors to the field operations CF.

\subsection{Hotspots in the CF of the Crops in Rotation}

Cauliflower, potato, and pepper had $\mathrm{CF}$ of 2,674, 2,661, and 2,609 $\mathrm{kgCO}_{2}$-eq, respectively (Table 4). These three crops had the greatest CFs among all crops in the farm's rotation.

\subsubsection{CF of Cauliflower Production}

Cauliflower ranked first in CF associated with its production in the farm studied. Fertilization, use of Reemay ${ }^{\circledR}$ as row cover for pest management, off-farm fuel use, and irrigation were the major contributors to the CF of cauliflower contributing $24 \%, 23 \%, 14 \%$, and $12 \%$ respectively (Table 4). This is similar to findings of O'Halloran et al. (2008) in which irrigation, fertilizer and machinery use were identified as the top three contributors to the CF of the Australian vegetable industry. The major difference in CF hotspots between the two studies is pest management. Organic growers use biological controls, allowed pesticides, strict sanitary control and physical controls like row covers for pest management (Code of Federal Regulations, title 7, sec. 205.206). Reemay ${ }^{\circledR}$ is a geotextile spun bonded non-woven fabric often used as row cover to aid early germination, reduce frost damage, and provide a physical barrier to insects. The material is porous to allow sunlight, moisture, and gases through while protecting the plants from pests. It is a popular choice for pest management among organic vegetable growers, but it was one of the major hotspots in the CF of the studied farm. 
In their studies on CF of vegetable production in Australia, O'Halloran et al. (2008) reported $4,570 \mathrm{~kg} \mathrm{CO}_{2}$-eq ha ${ }^{-1} \mathrm{yr}^{-1}$ for the production of cauliflower in Australia, which is higher than 2,500 kg CO 2 -eq ha ${ }^{-1} \mathrm{yr}^{-1}$ estimated in this study. O'Halloran et al. (2008) figures were arrived at using the industry average yield data without consideration for the size or the type of farming practices used. The average yield of cauliflower used in the study by O'Halloran et al. (2008) is $20 \mathrm{t} \mathrm{ha}^{-1}$ which is higher than the average yield of $17.2 \mathrm{t} \mathrm{ha}^{-1}$ of cauliflower in this study. This indicates that yield of cauliflower in the studied farm was $86 \%$ of the Australian industry average, yet CF was only $55 \%$ of the studied system in Australia.

\subsubsection{CF of Potato production}

Potato production had the second highest CF among crops in our study. Disking, fertilization, and off-farm fuel use were the top contributors to the CF of potato contributing $18 \%, 17 \%$, and 14\% respectively (Table 4 ). Seed potatoes accounted for $7.8 \%$ of the CF of potato. This was similar to $7.6 \%$ associated with seed in potato CF estimates by DEFRA (2009). There were two distinct CF burdens associated with seed potato: the inputs to grow the seed potato and the energy required to transport it to the farm given its substantial fresh mass. Previous studies have indicated that potato production tends to have substantial CF (Röös et al., 2010). Hillier et al. (2009) also found potato to have the highest CF among the crops examined in their studies. In the Hillier et al. (2009) study the CF of potato was estimated to be $1989.8 \mathrm{kgCO}_{2} \mathrm{ha}^{-1} \mathrm{yr}^{-1}$ which is lower than $2,661 \mathrm{kgCO}_{2} \mathrm{ha}^{-1} \mathrm{yr}^{-1}$ estimated for potato in our study. Understanding the hotspots in the CF of potato production is particularly important because of the strategic role of Washington State in potato production in the United States. Washington State grows about 20 
percent of the total U.S. potato crop (Washington State Potato Commission, 2013). Identifying CF's and hotspots of major crops in both conventional and alternative systems could be important in formulating policies for reduction of agricultural driven CF of the state.

\subsubsection{CF of Pepper production}

Pepper CF ranked third among the crops in the farm's rotation. Irrigation and the use of a mobile hoop house contributed the most to pepper CF accounting for $14 \%$ and $19 \%$ respectively (Table 4). The mobile hoop house is a portable hoop house constructed of a metal frame ( $3 \mathrm{~m}$ in height) and covered with a single layer of polyethylene. The mobile hoop house was used to extend the season and productivity of this crop. Grower records indicated that pepper grown under the mobile hoop house yielded approximately 50\% more than those in the open field. Peppers perform best when temperatures range between $65^{\circ}$ and $80^{\circ} \mathrm{F}$ during fruit setting (Rylski and Spigelman., 1982; Aloni et al., 2001). At this northern latitude of $45^{\circ} 45^{\prime} \mathrm{N}$ in a cool maritime climate, pepper production is marginal without microclimate modification such as a hoop house provides.

\subsection{CF of soil dynamics}

Some of the predicted environmental consequences of operating this farm are presented in Table 5. Values reported are those predicted after adjusting the harvest index down (for most crops) to approach the farmer's estimate of yield. Soil $\mathrm{N}_{2} \mathrm{O}-\mathrm{N}$ emission of $3.95 \mathrm{~kg} \mathrm{~N}_{2} \mathrm{O}-\mathrm{N} \mathrm{ha}^{-1} \mathrm{yr}^{-1}$ is equivalent to $1,840 \mathrm{Kg} \mathrm{CO}_{2}$-eq $\mathrm{ha}^{-1} \mathrm{yr}^{-1}$. This flux of $\mathrm{N}_{2} \mathrm{O}-\mathrm{N}$ is larger than any reported by Stöckle et al. (2012) from CropSyst simulations under conventional agriculture in eastern Washington but is similar to the average of $3.6 \mathrm{~kg} \mathrm{~N}_{2} \mathrm{O}-\mathrm{N} \mathrm{ha}^{-1} \mathrm{yr}^{-1}$ reported for European organic 
farms (Petersen et al., 2006) and the $5.4 \mathrm{~kg} \mathrm{~N}_{2} \mathrm{O}-\mathrm{N} \mathrm{ha}^{-1} \mathrm{yr}^{-1}$ reported for Germany (Flessa et al., 2002). Predicted $\mathrm{N}$ leaching losses of $43 \mathrm{~kg} \mathrm{~N} \mathrm{ha}^{-1} \mathrm{yr}^{-1}$ are somewhat smaller than the $53 \mathrm{~kg} \mathrm{~N}$ $\mathrm{ha}^{-1}$ applied as fertilizer each year. Predicted $\mathrm{N}$ uptake by crops was $195 \mathrm{~kg} \mathrm{~N} \mathrm{ha}^{-1} \mathrm{yr}^{-1}$, and $\mathrm{N}$

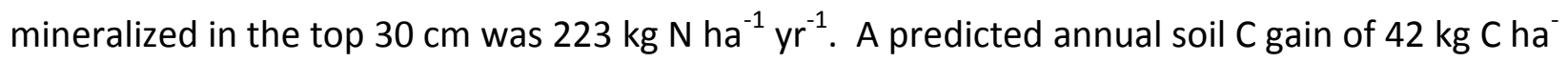
${ }^{1} \mathrm{yr}^{-1}$ in the top $5 \mathrm{~cm}$ of soil along with a loss of $5 \mathrm{~kg} \mathrm{Cha}^{-1} \mathrm{yr}^{-1}$ of residue $\mathrm{C}$ suggests effective humification in the top layer of soil. At 0 to $30 \mathrm{~cm} \mathrm{SOC} \mathrm{loss} \mathrm{of} 57 \mathrm{~kg} \mathrm{SOC} \mathrm{ha}^{-1} \mathrm{yr}^{-1}$ was predicted, equal to $210 \mathrm{Kg} \mathrm{CO}_{2}$-eq ha ${ }^{-1} \mathrm{yr}^{-1}$. However, residue $\mathrm{C}$ at 0 to $30 \mathrm{~cm}$ increased at the rate of $77 \mathrm{~kg}$ $\mathrm{C} \mathrm{ha}^{-1} \mathrm{yr}^{-1}$ (Table 5). When the residue $\mathrm{C}$ was added to the SOC, predicted overall change in SOC in the top $30 \mathrm{~cm}$ of soil was a gain of $20 \mathrm{~kg} \mathrm{Cha}^{-1} \mathrm{yr}^{-1}$, or about $73 \mathrm{Kg} \mathrm{CO}_{2}-\mathrm{eq} \mathrm{ha}{ }^{-1} \mathrm{yr}^{-1}$. Total soil GHG flux is $2293 \mathrm{Kg} \mathrm{CO}_{2}$-eq ha ${ }^{-1} \mathrm{yr}^{-1}$ which represented $12.4 \%$ of the farm CF (Table 4).

Simulated yields and associated harvest indices are presented in Table 6 for cash crops and cover crops under organic fertilizer conditions. Organic farmers often grow legume cover crops as an alternative to purchased fertilizers as the most economical way to provide plant-available N (Gaskell et al., 2000; Dorais, 2007). Removal of winter cover crops but leaving the 1-year cover crop reduced the simulated yield of all cash crops except dry beans and chard (Table 6). Since dry beans fix $\mathrm{N}$ their simulated yield was insensitive to the change in soil $\mathrm{N}$ that resulted from removal of cover crops. Chard yields were limited by low canopy coverage (Table S.7) and were therefore less sensitive to cover crop removal. Overall predicted yield among cash crops with just the 1-year rye-vetch cover was $89 \%$ of that with all cover crops included. Removal of all cover crops further reduced predicted yields in all cash crops except dry beans and chard (Table 6). Predicted yield of most crops were reduced by about $15 \%$ except winter squash for 
which yield was reduced by about 35\%. Since winter squash in this rotation followed about 18 months of leguminous cover crops, it was most affected by cover crop removal.

Simulated CF and $\mathrm{N}$ leaching without cover crops was greater than the CF and $\mathrm{N}$ leaching of organic vegetable production using cover crops. Although removal of all cover crops led to less $\mathrm{N}$ in the system, more $\mathrm{N}$ leaching was predicted (Table 5). Predicted $\mathrm{N}$ leached annually from the soil also increased from 43 to $57 \mathrm{~kg} \mathrm{~N} \mathrm{ha}^{-1} \mathrm{yr}^{-1}$ without winter cover crops (Table 5). The greater predicted leaching was due to more water drainage and less $\mathrm{N}$ uptake without the cover crops (data not shown). Without any cover crops, much more SOC was predicted to be lost (Table 5). From the top $30 \mathrm{~cm}, 498 \mathrm{~kg} \mathrm{Cha}^{-1} \mathrm{yr}^{-1}$ were lost without cover crops vs. 57 with cover crops, which translates to 1,826 and $209 \mathrm{~kg} \mathrm{CO}_{2}$-eq ha ${ }^{-1} \mathrm{yr}^{-1}$, respectively. Predicted $\mathrm{N}_{2} \mathrm{O}$ emission was higher with than without cover crops (Table 5) due to increased $\mathrm{N}$ available with

cover crops. $\mathrm{N}_{2} \mathrm{O}$ emission of $2.46 \mathrm{~kg} \mathrm{~N}_{2} \mathrm{O}-\mathrm{N} \mathrm{ha}^{-1} \mathrm{yr}^{-1}$ is equivalent to $1152 \mathrm{~kg} \mathrm{CO}_{2}$-eq ha ${ }^{-1} \mathrm{yr}^{-1}$. When the effect of $\mathrm{C}$ sequestration $(0-30 \mathrm{~cm})$ and $\mathrm{N}_{2} \mathrm{O}$ emission were considered together, simulated GWP with cover crops was 2,293 $\mathrm{Kg} \mathrm{CO}_{2}$-eq ha ${ }^{-1} \mathrm{yr}^{-1}$ and 3,865 $\mathrm{Kg} \mathrm{CO}_{2}$-eq ha-1 $\mathrm{yr}^{-1}$ without. Use of cover crops reduced predicted soil GHG emissions by $41 \%$.

\subsection{Functional Units and CF reporting}

The choice of functional unit (FU) can have a significant impact on study results, and thus must be considered to assess the relative embodied energy and GHG emissions associated with a product (Norman et al., 2006; Chau et al., 2015; Ruviaro et al., 2015). Aside from cover crops, which are not exported from the farm, chard and dry bush beans had the lowest CF per unit area, of 1,685 $\mathrm{kg} \mathrm{CO}_{2}$-eq ha-1 $\mathrm{yr}^{-1}$ and 1,698 $\mathrm{kg} \mathrm{CO}_{2}$-eq ha ${ }^{-1} \mathrm{yr}^{-1}$ respectively (Table 4). The result 
changed however when comparing the $\mathrm{CF}$ as $\mathrm{kg} \mathrm{CO}_{2}$-eq $\mathrm{kg}$ fresh yield ${ }^{-1}$ of the crops. The $\mathrm{CF}$ for dry bush beans of $0.623 \mathrm{~kg} \mathrm{CO}_{2}$-eq kg ${ }^{-1}$ crops is the greatest among all the crops grown by the farm. Potato which is one of the crops with the greatest CF in the rotation per unit area had the lowest $\mathrm{CF}$ per unit fresh mass $\left(0.045 \mathrm{~kg} \mathrm{CO}_{2}\right.$-eq kg fresh mass $\left.{ }^{-1}\right)$.

Dry bush bean had the highest footprint because of its lower yield mass compared to other crops and also because of its low water content compared to other vegetables. Potato had the lowest CF when reported on a fresh mass basis because of high yield mass and high water content of potato when compared to other crops in the farm's rotation. The difference in the CF of potato and dry bush beans, based on change in FU as observed in this study, further demonstrates the importance of FU in the estimation, comparison, and analysis of CF of any crop. It also brings to light the limitation of comparing the CF of different crops to each other. The FU chosen for reporting CF determines how the results may be used or interpreted.

\subsection{Comparing studies}

Few vegetables have been the subject of multiple complete CF studies, except onions. The CF of 0.046 (field boundary) or $0.079 \mathrm{~kg}$ (expanded boundary) $\mathrm{CO}_{2}$-eq $\mathrm{kg}^{-1}$ estimated for onions in this study (Table 4) is similar to other findings. Saunders et al. (2006) reported emissions of $0.059 \mathrm{~kg}$ $\mathrm{CO}_{2}$-eq kg ${ }^{-1}$ for conventional onions produced in New Zealand (NZ) versus $0.042 \mathrm{~kg} \mathrm{CO}_{2}$-eq kg

${ }^{1}$ for onions produced in the United Kingdom (UK). The CF of subsequent shipping of NZ onions to UK or controlled storage in UK was $0.125 \mathrm{~kg} \mathrm{CO}_{2}$-eq $\mathrm{kg}^{-1}$, dwarfing either on-farm CF. A similar study determined CF (field boundary) of $0.039 \mathrm{~kg} \mathrm{CO}_{2}$-eq $\mathrm{kg}^{-1}$ for onions grown in Sweden and $0.046 \mathrm{~kg} \mathrm{CO}_{2}$-eq $\mathrm{kg}^{-1}$ for onions grown in Denmark (Lagerberg-Fogelberg and 
Carlsson-Kanyamaet, 2006). Both of these studies relied on average data from onion industry reports in their respective countries and neither included direct GHG emissions from soil except from lime use.

\subsection{Whole farm CF}

The total CF of the studied farm with an expanded boundary was $18,472 \mathrm{~kg} \mathrm{CO}_{2}$-eq ha ${ }^{-1} \mathrm{yr}^{-1}$. This expanded boundary CF included infrastructure such as deer fencing, a greenhouse, and soil emissions (Table 4), which are often overlooked in CF studies. Using a boundary of the farm field, more similar to other studies (Lagerberg-Fogelberg and Carlsson-Kanyama, 2006; Hillier et al., 2009) which excludes soil emissions, farm infrastructures, and off-farm fuel use for production, the CF of the studied operation was $11,419 \mathrm{CO}_{2}$ - eq $\mathrm{ha}^{-1} \mathrm{yr}^{-1}$. The selection of a field-only vs whole-farm system boundary therefore affected CF estimation by $38 \%$.

Fuel use both for on-farm and off-farm operation, was the primary CF hotspot in the whole farm. The CF of gasoline and diesel can be allocated among the crops based on the management practices for each crop. Production of chard had the highest CF associated with fuel usage in the studied farm, followed by onion and potato. Weed management in chard production involves several passes of a basket weeder, which explains the high fuel CF of chard. The 10-fold increase in the global energy budget for agricultural activities since the start of the twentieth century (Boyle, 2004) suggest that there is room for improvement in agricultural use of fossil fuel (Smith et al., 2015)

The farm's greenhouse had a total CF of $959 \mathrm{kgCO}_{2}$-eq $\mathrm{ha}^{-1} \mathrm{yr}^{-1}$, which included both the physical structure and materials used. The greenhouse is used for production of transplants for 
five of the cash crops used in this study. On the other hand, a CF of only $222 \mathrm{kgCO}_{2}-\mathrm{eq} \mathrm{ha}^{-1} \mathrm{yr}^{-1}$ is associated with the seed for three crops that do not use the greenhouse, including potato with a CF for seed of $208 \mathrm{kgCO}_{2}-\mathrm{eq} \mathrm{ha} \mathrm{hr}^{-1}$. On-farm production of seedlings in the farm's greenhouse had a higher CF than seed purchased off-farm. However established seedlings are necessary for some crops to reach production in this area. The constituents of the greenhouse CF are thus worth further exploration.

A greenhouse is often considered an essential facility in organic vegetable production in many climates. However, the materials and tools used in a greenhouse can have considerable CF as found in this study. With a CF of $270 \mathrm{~kg} \mathrm{CO}_{2}$-eq ha- $\mathrm{yr}^{-1}$, the use of peat in the studied farm greenhouse contributed most to the greenhouse CF (Fig 2). The greenhouse potting mix (3:1 peat and perlite) also had a high $\mathrm{CF}, 264 \mathrm{~kg} \mathrm{CO}_{2}-\mathrm{eq} \mathrm{ha}{ }^{-1} \mathrm{yr}^{-1}$. Peat is a common material used as a greenhouse potting medium. The use of peat is also unsustainable by other measures, with a regeneration rate of peatland in Finland about 85 times slower than the commercial peat removal rate (Schilstra, 2001). Furthermore, the mining of peat is responsible for the loss of non-energy assets like biodiversity, landscape amenities, and historic archives (Winkler and DeWitt, 1985; Knight, 1991; Shaw, 2000).

Apart from compost use in the greenhouse which also has a considerable $\mathrm{CF}$ of $238 \mathrm{~kg} \mathrm{CO}$-eq $\mathrm{ha}^{-1} \mathrm{yr}^{-1}$, other materials and activities (including the greenhouse structure) have a relatively low CF. Thus, finding alternatives for the use of peat and purchased compost in the greenhouse would be a worthwhile option for the reduction of the farm's CF.

\subsection{Alternative farm inputs for CF reduction}


Irrigation was a major contributor to the CF of the three crops identified as hotspots in the farm production. Irrigation per ha was greatest on pepper (14\%) followed by cauliflower (12\%). These are late season crops and required more irrigation in the late summer when demand was high. A considerable amount of energy is required to make water available to crops. These three crops hold great potential to reduce the farms total CF by altering management decisions. Fertilizing and disking were two other activities that contributed substantially to the CF of each of the three hotspot crops. Fertilizing CF per ha was greatest on cauliflower (23\%) followed by potato (16\%). Disking CF per ha was greatest on potato (18\%) followed by peppers (14\%). So adjustments to the management of cauliflower and potato could have considerable impact in reducing the $\mathrm{CF}$ of the farm. Also, the high $\mathrm{CF}$ associated with the use of some specialized materials like row cover (Reemay ${ }^{\circledR}$ ) for cauliflower, and mobile hoop house for pepper production also indicate that alternatives to their management could reduce the CF of the farm.

The simulation of a switch by the farm to the use of biodiesel (instead of gasoline and diesel) reduced total CF by $32 \%$, use of a solar powered irrigation system (in place of the current PNW $90 \%$ hydro powered system) reduced total CF by $2 \%$, and the combination reduced total CF $34 \%$, from $18,478 \mathrm{~kg} \mathrm{CO}_{2}$-eq ha $\mathrm{yr}^{-1}$ to $12,158 \mathrm{~kg} \mathrm{CO}_{2}-\mathrm{eq} \mathrm{ha}{ }^{-1} \mathrm{yr}^{-1}$. The simulated reduction in the farm CF included a reduction in the CF of every crop, since all (cash) crops used fuel and irrigation (Fig 3). A proposed shift to biodiesel also changed the hotspots among the crops grown by the farm. Under the biodiesel scenario cauliflower had the highest CF of 2,207 $\mathrm{kgCO}_{2}$ -eq ha ${ }^{-1} \mathrm{yr}^{-1}$ against the previous 2,675 $\mathrm{kg} \mathrm{CO}_{2}$-eq ha ${ }^{-1} \mathrm{yr}^{-1}$ in the status quo scenario (Fig 3). 
Biodiesel use has a high potential to reduce agricultural CF as it only releases the $\mathrm{CO}_{2}$ that the biofuel crops absorbed while growing. In our study, the CF allotted to biodiesel was only due to processing of the biodiesel from its feedstock. However, adoption of biofuels and biodiesel at global scale could put further pressure on forests, native grasslands and the food supply (Melillo et al., 2009). Land use change in this scenario as a result of conversion of forest to cropland could lead to loss of sequestered $\mathrm{C}$ to the atmosphere, a situation that could significantly increase the emission cost of liquid biofuels (Searchinger et al., 2008; Melillo et al., 2009).

\section{Summary and Conclusions}

Effective mitigation by agriculture of GHG emissions and hence global climate change requires identification of significant CF and GHG sources or hotspots in agricultural production systems. Our study of a small organic vegetable farm identified fuel use, organic fertilizer, and irrigation as the major hotspots in the CF. Cauliflower, potato and pepper crops had the highest CF ha ${ }^{-1}$ among the crops grown in this test case. The use of biodiesel in place of gasoline and diesel combined with the use of solar powered irrigation system in place of grid powered irrigation systems could reduce the CF of the farm by $34 \%$. Specialized plastic materials (i.e., hoop house for pepper and row cover for cauliflower) with high CF might be replaced or their lifespan might be extended to reduce annual CF. This study also established that the absolute values of the CF estimated for various crops may vary, depending on materials and activities included in the chosen system boundaries. Estimation of CF will be useful in identifying hotspots of materials and activities with the largest targets for CF reduction. This will enable farmers, businesses, and 
policymakers to innovate and focus efforts on finding viable alternatives that provide the greatest benefit to reducing the carbon footprint of agriculture.

\section{Acknowledgements}

This material is based upon work that is supported by the Organic Research and Extension Initiative, National Institute of Food and Agriculture, U.S. Department of Agriculture, under award number 2010-51300-21620.

Any opinions, findings, conclusions, or recommendations expressed in this publication are those of the author(s) and do not necessarily reflect the view of the U.S. Department of Agriculture.

We are grateful to B. Weddell for collection of field data. 


\section{REFERENCES}

Adewale, C. A., 2013. Carbon footprint and nutrient bio-availability assessment of organic systems. MS thesis, WSU.

Aloni, B., Peet, M., Pharr, M., Karni, L., 2001. The effect of high temperature and high atmospheric $\mathrm{CO}_{2}$ on carbohydrate changes in bell pepper (Capsicum annuum) pollen in relation to its germination. Physiologia Plantarum, 112 (4), 505-512.

Andersson, K., Ohlsson, T., Olsson, P. 1994., Life cycle assessment (LCA) of food products and production systems. Trends in Food Science \& Technology, 5(5), 134-138.

Batjes, N. H., 1998. Mitigation of atmospheric $\mathrm{CO}_{2}$ concentrations by increased carbon sequestration in the soil. Biology and Fertility of Soils, 27(3), 230-235.

Bélanger, G. W., J. R., Walsh, J. R., Richards, J. E., Milburn, P. H., Ziadi, N., 2001. Critical nitrogen curve and nitrogen nutrition index for potato in eastern Canada. American Journal of Potato Research 78, 355-364.

Boyle, G., 2004 Renewable Energy: Power for a sustainable future, 2nd ed. Miltonnes Keynes, UK. Oxford University Press.

Castellvi, F., Stöckle, C.O., 2001. Comparing the performance of WGEN and ClimGen in the generation of temperature and solar radiation. Transactions of the American Society of Agricultural Engineers 44, 1683-1687.

Cederberg, C., Mattsson, B., 2000. Life cycle assessment of milk production-a comparison of conventional and organic farming. Journal of Cleaner Production, 8(1), 49-60. 
Chau, C. K., Leung, T. M., Ng, W. Y., 2015. A review on life cycle assessment, life cycle energy assessment and life cycle carbon emissions assessment on buildings. Applied Energy, 143, 395-413.

Conant, R.T., Paustian, K., Elliott, E.T., 2001. Grassland management and conversion into grassland: effects on soil carbon. Applied Ecology 11, 343- 355.

De Boer, I. J., 2003. Environmental impact assessment of conventional and organic milk production. Livestock Production Science, 80(1), 69-77.

de Ponti, T., Rijk, B., van Ittersum, M. K., 2012. The crop yield gap between organic and conventional agriculture. Agricultural Systems 108, 1-9.

DEFRA, Department for Environment, Food and Rural Affairs, 2009. Comparative life cycle assessment of food commodities procured for UK consumption through a diversity of supply chains. Report FO0103, SID 5, Manchester Business School, London

Dick, J., Smith, P., Smith, R., Lilly, A., Moxey, A., Booth, J., Campbell, C., Coulter, D., 2008. Calculating farm scale greenhouse gas emissions. University of Aberdeen, Carbon Plan, the Macaulay Institute, Pareto consulting, SAOS Ltd, Scotland, UK.

Dorais, M., 2007. Organic production of vegetables: state of the art and challenges. Canadian Journal of Plant Science, 87(5), 1055-1066.

EPA, 2008. Inventory of U.S. Greenhouse Gas Emissions and Sinks: 1990-2006. EPA 430-R-08005. U.S. Environmental Protection Agency, Washington, DC.

EPA, 2011. Inventory of US greenhouse gas emissions and sinks: 1990-2009. EPA 430-R-11-005. 
Flessa, H., Ruser, R., Dörsch, P., Kamp, T., Jimenez, M. A., Munch, J. C., and Beese, F., 2002. Integrated evaluation of greenhouse gas emissions $\left(\mathrm{CO}_{2}, \mathrm{CH}_{4}, \mathrm{~N}_{2} \mathrm{O}\right)$ from two farming systems in southern Germany. Agriculture, Ecosystems \& Environment, 91(1), 175-189.

Foster, C., Green, K., Bleda, M., 2006. Environmental impacts of food production and consumption: final report to the Department for Environment Food and Rural Affairs. DEFRA, London.

Gaskell, G., Allum, N., Bauer, M., Durant, J., Allansdottir, A., Bonfadelli, H., Wagner, W., 2000. Biotechnology and the European public. Nature Biotechnology, 18(9), 935-938.

Gattinger, A., Muller, A., Haeni, M., Skinner, C., Fliessbach, A., Buchmann, N., Niggli, U., 2012. Enhanced top soil carbon stocks under organic farming. Proceedings of the National Academy of Sciences, 109(44), 18226-18231.

Hillier, J., Hawes, C., Squire, G., Hiltonnes, A., Wale, S., Smith, P., 2009. The carbon footprints of food crop production. International Journal of Agricultural Sustainability, 7(2), 107-118.

IPCC, 2006. IPCC guidelines for national greenhouse gas inventories, volume 4. Agriculture, forestry and other land use. Intergovernmental Panel on Climate Change.

IPCC, 2007. Climate Change 2007: The Physical Science Basis. Working Group I. Cambridge Univ. Press, Cambridge, UK. Agenda 6(07), 333.

IPCC, 2014: Climate Change 2014: Mitigation of Climate Change. Contribution of Working Group III to the Fifth Assessment Report of the Intergovernmental Panel on Climate Change [Edenhofer, O., R. Pichs-Madruga, Y. Sokona, E. Farahani, S. Kadner, K. Seyboth, A. Adler, I. Baum, S. Brunner, P. Eickemeier, B. Kriemann, J. Savolainen, S. Schlömer, C. von Stechow, T. 
Zwickel and J.C. Minx (eds.)]. Cambridge University Press, Cambridge, United Kingdom and New York, NY, USA.

Kauppi, P. E., Sedjo, R., 2001. Technological and economic potential of options to enhance, maintain, and manage biological carbon reservoirs and geo-engineering. Climate Change, 301-343.

Knight, D., 1991. Growing threats to peat. New Scientist 3, 27-32.

Kotschi, J., Müller-Sämann, K., 2004. The role of organic agriculture in mitigating climate change. International Federation of Organic Agriculture Movements (IFOAM), Bonn.

Lagerberg-Fogelberg, C., Carlsson-Kanyama, A., 2006. Environmental assessment of foods-An LCA inspired approach. Environmental Information in Food Supply System. FOI, Stockholm.

Lal R., Kimble, J. M., Follett R. F., and Cole, C. V., 1999. Potential of United States Cropland to Sequester Carbon and Mitigate the Greenhouse Effect. CRC Press, Boca Raton, Florida.

Lal, R., 2001. Potential of desertification control to sequester carbon and mitigate the greenhouse effect. Climate Change 15, 35- 72.

Lal, R., 2004a. Soil carbon sequestration to mitigate climate change. Geoderma, 123(1), 1-22.

Lal, R., 2004b. Soil carbon sequestration impacts on global climate change and food security. Science, 304(5677), 1623-1627.

Lal, R., Bruce, J.P., 1999. The potential of world cropland soils to sequester C and mitigate the greenhouse effect. Environmental Science and Policy 2, 177-185.

Lawson, A, F. M. Fortuna, C Cogger, A. Bary and T. Stubbs. 2013. Nitrogen contribution of ryehairy vetch cover crop mixtures to organically grown sweet corn. Renewable Agriculture and Food Systems, 28(01), 59-69. 
Leavitt, M. J., C. C. Sheaffer, D. L. Wyse and D. L. Allan. 2011. Rolled winter rye and hairy vetch cover crops lower weed density but reduce vegetable yields in no-tillage organic production. HortScience 46, 387-395.

Leithold, G., Hülsbergen, K. J., Brock, C. 2015. Organic matter returns to soils must be higher under organic compared to conventional farming. Journal of Plant Nutrition and Soil Science, 178(1), 4-12.

Lynas, M., 2007. Carbon counter. Harper Collins Publishers, Glasgow, UK.

Marriott, E. E., and Wander, M. M., 2006. Total and labile soil organic matter in organic and conventional farming systems. Soil Science Society of America Journal, 70(3), 950-959.

Meisterling, K., Samaras, C., Schweizer, V., 2009. Decisions to reduce greenhouse gases from agriculture and product transport: LCA case study of organic and conventional wheat. Journal of Cleaner Production, 17(2), 222-230.

Melillo, J. M., Reilly, J. M., Kicklighter, D. W., Gurgel, A. C., Cronin, T. W., Paltsev, S., Schlosser, C. A., 2009. Indirect emissions from biofuels: how important? Science, 326(5958), 13971399.

Millennium Ecosystem Assessment. 2005. Ecosystems and human well-being: Synthesis. Island Press, WA.

Monastersky, R., 2013. Global carbon dioxide levels near worrisome milestone. Nature, 497(7447), 13-14.

Monti, A., Fazio, S., Venturi, G., 2009. Cradle-to-farm gate life cycle assessment in perennial energy crops. European Journal of Agronomy, 31(2), 77-84. 
Moxey, A., 2008. Reviewing and Developing Agricultural Responses to Climate Change. Report prepared for the Scottish Government Rural and Environment Research and Analysis Directorate (SG-RERAD) Agricultural and Climate Change Stakeholder Group (ACCSG). Report No. CR/2007/11. Pareto Consulting, Edinburgh.

Nemecek, T., Kägi, T., 2007. Life cycle inventories of agricultural production systems. Ecoinvent report version, 2, 15 .

NOAA National Climatic Data Center (http://www.ncdc.noaa.gov/cdoweb/datasets/GHCND:US1WACK0022/detail)

Norman, J., MacLean, H. L., Kennedy, C. A., 2006. Comparing high and low residential density: life-cycle analysis of energy use and greenhouse gas emissions. Journal of Urban Planning and Development, 132(1), 10-21.

O'Halloran, N. J., Fisher, P. D., Rab, M. A., 2008. Vegetable industry carbon footprint scoping study: preliminary estimation of the carbon footprint of the Australian vegetable industry. Discussion paper 4.

Ostrom, M., Donovan, C., 2013, Profile of Small Farms in Washington State Agriculture. Washington State University Extension Factsheet. FS 072 E.

Petersen, S. O., Regina, K., Pöllinger, A., Rigler, E., Valli, L., Yamulki, S., and Vinther, F. P., 2006. Nitrous oxide emissions from organic and conventional crop rotations in five European countries. Agriculture, ecosystems \& environment, 112(2), 200-206.

Pimentel, D., 2006. Soil erosion: a food and environmental threat. Environment, development and sustainability, 8(1), 119-137. 
Prather, M., Derwent, R., Ehhalt, D., Fraser, P., Sanhueza, E., and Zhou, X., 1995. Other Trace Gases and. Climate Change, 1994: Radiative Forcing of Climate Change and an Evaluation of the IPCC IS92 Emission Scenarios, 73.

Röös, E., Sundberg, C., \& Hansson, P. A., 2010. Uncertainties in the carbon footprint of food products: a case study on table potatoes. The International Journal of Life Cycle Assessment, 15(5), 478-488.

Ruviaro, C. F., de Léis, C. M., Lampert, V. D. N., Barcellos, J. O. J., Dewes, H. 2015. Carbon footprint in different beef production systems on a southern Brazilian farm: a case study. Journal of Cleaner Production, 96, 435-443.

Saunders, C., Barber, A., Taylor, G., 2006. Food miles-comparative energy/emissions performance of New Zealand's agriculture industry. Research Report 285, Lincoln University. Agribusiness and Economics Research Unit.

Saunders, C., Barber, A., 2008. Carbon footprints, life cycle analysis, food miles: Global trade trends and market issues. Political Science, 60(1), 73-88.

Schilstra, A. J., 2001. How sustainable is the use of peat for commercial energy production? Ecological Economics, 39(2), 285-293.

Scialabba, N. E. H., Müller-Lindenlauf, M., 2010. Organic agriculture and climate change. Renewable Agriculture and Food Systems, 25(02), 158-169.

Searchinger, T., Heimlich, R., Houghton, R. A., Dong, F., Elobeid, A., Fabiosa, J., Yu, T. H. 2008. Use of US croplands for biofuels increases greenhouse gases through emissions from landuse change. Science, 319(5867), 1238-1240. 
Shaw, A., 2000. Peat campaigns-fair business or exaggeration? Peatlands International. 1, 1013.

Smith, L. G., Williams, A. G., Pearce, B. D. 2015. The energy efficiency of organic agriculture: A review. Renewable agriculture and Food systems, 30(03), 280-301.

Snyder, C.S., Bruulsema, T.W., 2007. Nutrient Use Efficiency and Effectiveness in North America: Indices of Agronomic and Environmental Benefit. International Plant Nutrition Institute. June 2007. Reference \# 07076. 4 pp.

Snyder, C. S., Bruulsema, T. W., Jensen, T. L., Fixen, P. E., 2009. Review of greenhouse gas emissions from crop production systems and fertilizer management effects. Agriculture, Ecosystems \& Environment, 133(3), 247-266.

Soil Survey Staff, National Resources Conservation Service, United States Department of Agriculture, Web Soil Survey. Available online at http://websoilsurvey.nrcs.usda.gov/. Accessed 8/31/2016.

Soil Survey Staff, Natural Resources Conservation Service, United States Department of Agriculture. U.S. General Soil Map (STATSGO2). Available online at http://www.nrcs.usda.gov/wps/portal/nrcs/detail/soils/survey/geo/?cid=nrcs142p2 05362 $\underline{9}$. Accessed 8/31/2016.

Stöckle, C. O., Martin, S. A., Campbell, G. S., 1994. CropSyst, a cropping systems simulation model: water/nitrogen budgets and crop yield. Agricultural Systems, 46(3), 335-359.

Stöckle, C. O., Donatelli, M., Nelson, R., 2003. CropSyst, a cropping systems simulation model. European Journal of Agronomy, 18(3), 289-307. 
Stöckle, C., Higgins, S., Kemanian, A., Nelson, R., Huggins, D., Marcos, J., Collins, H., 2012. Carbon storage and nitrous oxide emissions of cropping systems in eastern Washington: A simulation study. Journal of Soil and Water Conservation. 67,365-377.

Washington State Potato Commission. Available online at http://www.potatoes.com/ourindustry/history/ Accessed 8/31/2016.

Wells, C. M., 2001. Total energy indicators of agricultural sustainability: dairy farming case study. Technical paper 2001/3, University of Otago, New Zealand.

Wiedmann, T., Minx, J., 2008. A definition of 'carbon footprint'. Ecological Economics Research Trends, 1, 1-11.

Winkler, M.G., DeWitt, C.B., 1985. Environmental impacts of peat mining in the United States: Documentation for wetland conservation. Environmental Conservation. 12, 317-330

Wood, R., Lenzen, M., Dey, C., Lundie, S., 2006. A comparative study of some environmental impacts of conventional and organic farming in Australia. Agricultural Systems, 89(2), 324348.

Zaher, U., S. Higgins and L. Carpenter-Boggs. 2016. Interactive life cycle assessment framework to evaluate agricultural impacts and benchmark emission reduction credits from organic management J. Cleaner Prod. Doi: 10.1016/j.jclepro.2015.12.073.

\section{Tables}

Table 1. Inventory of field operations applied in the production of each crop in a 10 year crop series simulated for a western Washington certified organic farm. 


\begin{tabular}{|c|c|c|}
\hline Crop & Field operation ${ }^{a}$ & Quantity \\
\hline \multirow[t]{6}{*}{ 1-year rye/vetch } & Plant, broadcast & $0.45 \mathrm{~kg}$ \\
\hline & Spread lime & $409 \mathrm{~kg} \mathrm{ha}^{-1}$ \\
\hline & Irrigate & $250 \mathrm{~mm}$ \\
\hline & Mow & $2673 \mathrm{~m}^{2}$ \\
\hline & Rip & $891 \mathrm{~m}^{2}$ \\
\hline & Disk & $1782 \mathrm{~m}^{2}$ \\
\hline \multirow[t]{10}{*}{ Winter squash } & Plant by hand & $1.7 \mathrm{~kg}$ \\
\hline & ${ }^{\mathrm{b}}$ Fertilize, broadcast & $781 \mathrm{~kg} \mathrm{ha}^{-1}$ \\
\hline & Irrigate & $250 \mathrm{~mm}$ \\
\hline & Rototill & $891 \mathrm{~m}^{2}$ \\
\hline & Mechanical weeding & $3564 \mathrm{~m}^{2}$ \\
\hline & Manual weeding & $891 \mathrm{~m}^{2}$ \\
\hline & Harvest by hand & $891 \mathrm{~m}^{2}$ \\
\hline & Transport van & $10.27 \mathrm{t}-\mathrm{km}$ \\
\hline & Mow & $1782 \mathrm{~m}^{2}$ \\
\hline & Disk & $2673 \mathrm{~m}^{2}$ \\
\hline \multirow[t]{7}{*}{ Potato } & Plant by hand & $108 \mathrm{~kg}$ \\
\hline & Irrigate & $250 \mathrm{~mm}$ \\
\hline & Fertilize, broadcast & $1192 \mathrm{~kg} \mathrm{ha}^{-1}$ \\
\hline & Rip & $891 \mathrm{~m}^{2}$ \\
\hline & Rototill & $891 \mathrm{~m}^{2}$ \\
\hline & Open furrow & $891 \mathrm{~m}^{2}$ \\
\hline & Mechanical weeding & $2673 \mathrm{~m}^{2}$ \\
\hline
\end{tabular}




\begin{tabular}{|c|c|c|}
\hline & Manual hilling & $2673 \mathrm{~m}^{2}$ \\
\hline & Harvest digger & $891 \mathrm{~m}^{2}$ \\
\hline & Transport van & $10.27 \mathrm{t}-\mathrm{km}$ \\
\hline & Mow & $891 \mathrm{~m}^{2}$ \\
\hline & Disk & $2673 \mathrm{~m}^{2}$ \\
\hline Dry bush beans & Plant by hand & $6.94 \mathrm{~kg}$ \\
\hline & Irrigate & $250 \mathrm{~mm}$ \\
\hline & Fertilize, broadcast & $781 \mathrm{~kg} \mathrm{ha}^{-1}$ \\
\hline & Rototill & $891 \mathrm{~m}^{2}$ \\
\hline & Mechanical weeding & $1782 \mathrm{~m}^{2}$ \\
\hline & Manual weeding & $891 \mathrm{~m}^{2}$ \\
\hline & Harvest by hand & $891 \mathrm{~m}^{2}$ \\
\hline & Mow & $891 \mathrm{~m}^{2}$ \\
\hline & Disk & $3564 \mathrm{~m}^{2}$ \\
\hline Chard & Plant by hand & $0.5 \mathrm{~kg}$ \\
\hline & Irrigate & $280 \mathrm{~mm}$ \\
\hline & Fertilize, broadcast & $781 \mathrm{~kg} \mathrm{ha}^{-1}$ \\
\hline & Rototill & $891 \mathrm{~m}^{2}$ \\
\hline & Mechanical weeding & $5346 \mathrm{~m}^{2}$ \\
\hline & Harvest by hand & $891 \mathrm{~m}^{2}$ \\
\hline & Mow & $891 \mathrm{~m}^{2}$ \\
\hline & Disk & $2673 \mathrm{~m}^{2}$ \\
\hline Summer squash & Plant by hand & $1.7 \mathrm{~kg}$ \\
\hline & Irrigate & $330 \mathrm{~mm}$ \\
\hline
\end{tabular}




\begin{tabular}{|c|c|c|}
\hline & Fertilize, broadcast & $976.3 \mathrm{~kg} \mathrm{ha}^{-1}$ \\
\hline & Rototill & $891 \mathrm{~m}^{2}$ \\
\hline & Harvest by hand & $891 \mathrm{~m}^{2}$ \\
\hline & Mow & $1782 \mathrm{~m}^{2}$ \\
\hline & Disk & $3564 \mathrm{~m}^{2}$ \\
\hline Sweet pepper & Plant by hand & $1.7 \mathrm{~kg}$ \\
\hline & Irrigate & $430 \mathrm{~mm}$ \\
\hline & Fertilize, broadcast & $976.3 \mathrm{~kg} \mathrm{ha}^{-1}$ \\
\hline & Rototill & $891 \mathrm{~m}^{2}$ \\
\hline & Mechanical weeding & $1782 \mathrm{~m}^{2}$ \\
\hline & Manual weeding & $3564 \mathrm{~m}^{2}$ \\
\hline & Harvest by hand & $891 \mathrm{~m}^{2}$ \\
\hline & Mow & $1782 \mathrm{~m}^{2}$ \\
\hline & Disk & $2673 \mathrm{~m}^{2}$ \\
\hline Onion bulb & Plant by hand & $1.7 \mathrm{~kg}$ \\
\hline & Irrigate & $80 \mathrm{~mm}$ \\
\hline & Fertilize, broadcast & $596 \mathrm{~kg} \mathrm{ha}^{-1}$ \\
\hline & Rototill & $891 \mathrm{~m}^{2}$ \\
\hline & Mechanical weeding & $6237 \mathrm{~m}^{2}$ \\
\hline & Manual weeding & $5346 \mathrm{~m}^{2}$ \\
\hline & Harvest by hand & $891 \mathrm{~m}^{2}$ \\
\hline & Mow & $1782 \mathrm{~m}^{2}$ \\
\hline & Disk & $3564 \mathrm{~m}^{2}$ \\
\hline Cauliflower & Plant by hand & $1.7 \mathrm{~kg}$ \\
\hline
\end{tabular}




\begin{tabular}{ll} 
Irrigate & $360 \mathrm{~mm}$ \\
Install Remay & \\
Fertilize, broadcast & $1608 \mathrm{~kg} \mathrm{ha}^{-1}$ \\
Rototill & $1782 \mathrm{~m}^{2}$ \\
Manual weeding & $891 \mathrm{~m}^{2}$ \\
Harvest by hand & $891 \mathrm{~m}^{2}$ \\
Mow & $891 \mathrm{~m}^{2}$ \\
Plant, broadcast & $891 \mathrm{~m}^{2}$ \\
Mow & $891 \mathrm{~m}^{2}$ \\
Disk & $891 \mathrm{~m}^{2}$ \\
Plant, broadcast & $891 \mathrm{~m}^{2}$ \\
Mow & $1782 \mathrm{~m}^{2}$ \\
Rototill & $891 \mathrm{~m}^{2}$ \\
\hline
\end{tabular}

${ }^{\mathrm{a}}$ For associated operation to be programed in CropSyst, see Adewale, 2013.

${ }^{\mathrm{b}} \mathrm{A}$ special blend of organic fertilizer is used by the farm.

${ }^{\mathrm{C}}$ Reemay ${ }^{\circledR}$ is used as row cover for both microclimate conditioning and pest control for cauliflower production.

Table 2 Inventory of the farm implements, dimension, power and source of power used on a certified organic vegetable farm in western Washington State.

\begin{tabular}{llcccc}
\hline Equipment & Model or Type & Power (hp) & Width & Weight & Source of power \\
& & $(\mathrm{m})$ & $(\mathrm{kg})$ & \\
\hline Tractors & John Deere 3520 & 35 & 1450 & diesel \\
& Farmall A & 13 & 1360 & gasoline
\end{tabular}


Allis Chalmers G

10

583 gasoline

\begin{tabular}{|c|c|c|c|c|c|}
\hline \multirow[t]{8}{*}{ Tillage Implements } & \multicolumn{2}{|l|}{ Rototiller } & \multicolumn{2}{|l|}{1.52} & John Deere 3520 \\
\hline & \multicolumn{2}{|l|}{ Rinieri flail mower } & 1.22 & 282 & John Deere 3520 \\
\hline & \multicolumn{2}{|l|}{ Rotary mower } & 1.52 & 567 & Farmall A \\
\hline & \multicolumn{2}{|l|}{ Tandem disk } & 1.52 & 170 & John Deere 3520 \\
\hline & \multicolumn{2}{|l|}{ Sub-soiler single shank } & 1.52 & 103 & John Deere 3520 \\
\hline & Troy Bilt ‘Horse’ walking & 6 & 0.5 & 152 & gasoline \\
\hline & \multicolumn{5}{|l|}{ tiller } \\
\hline & \multicolumn{2}{|l|}{ Mantis Classic 2 Cycle Tiller } & 0.35 & 10 & gasoline \\
\hline Weeding & Drangen Weeding Platform & 13 & 2.4 & & gasoline \\
\hline Implements & Basket Weeder & & 1.52 & & Allis Chalmers \\
\hline
\end{tabular}


Table 3. Inventory of the infrastructures, energy, materials, dimensions and estimated lifespan as used on a certified organic vegetable farm in western Washington State.

\begin{tabular}{|c|c|c|c|c|c|}
\hline Structure or system & Material & Dimension & $\begin{array}{l}\text { Mass } \\
(\mathrm{kg})\end{array}$ & Quantity & Lifespan (yr) \\
\hline \multirow[t]{8}{*}{ Greenhouse } & Perlite & & 91 & & 1 \\
\hline & Peat moss & & 280 & & 1 \\
\hline & Compost & & 271 & & 1 \\
\hline & Plastic sheets & & 1.2 & & 5 \\
\hline & Field crates & & 25 & & 5 \\
\hline & Soil mix & & 620 & & 1 \\
\hline & Galvanized & & 130 & & 10 \\
\hline & steel & & & & \\
\hline \multirow[t]{2}{*}{ Mobile hoop house } & Plastic cover & $300 \mathrm{~m}^{2}$ & & & 7 \\
\hline & Steel tubes & $10 \mathrm{~m}$ & & 30 & 7 \\
\hline \multirow[t]{2}{*}{ Deer fencing } & Iron post & $5 \mathrm{~cm} \times 3 \mathrm{~m}$ & & 84 & 15 \\
\hline & Poly fencing & $986 \mathrm{~m}^{2}$ & & & 10 \\
\hline Drip Irrigation & Drip tapes & $5400 \mathrm{~m}$ & 104 & & 4 \\
\hline systems & Pump & 7.5hp & & & \\
\hline \multicolumn{6}{|l|}{ Energy } \\
\hline Electricity & & & & $1000 \mathrm{kwh}$ & \\
\hline Gasoline & & & & 1275 liters & \\
\hline Diesel & & & & 625 liters & \\
\hline
\end{tabular}


Table: 4. Carbon footprint ( $\mathrm{kg} \mathrm{CO}_{2}$ - eq $\mathrm{ha}^{-1} \mathrm{yr}^{-1}$ ) of inputs and operations of crops in a farm rotation with traditional field boundary and an expanded total farm boundary. Total carbon footprint is shown per ha and per $\mathrm{kg}$ fresh crop.

\begin{tabular}{|c|c|c|c|c|c|c|c|c|c|c|}
\hline \multirow[t]{2}{*}{ Item } & Winter & Potato & Dry bush & Chard & Summer & Peppers & Onion & Cauliflower & Cover & Total \\
\hline & squash & & beans & & \multicolumn{4}{|l|}{ squash } & \multicolumn{2}{|l|}{ crops } \\
\hline \multicolumn{11}{|l|}{ Field boundary } \\
\hline Mowing & 36 & 18 & 18 & 18 & 36 & 36 & 18 & 36 & 54 & 270 \\
\hline Disking & 352 & 470 & 352 & 352 & 470 & 352 & 470 & 117 & 117 & 3051 \\
\hline Weeding & 41 & 31 & 21 & 62 & 0 & 21 & 72 & 0 & 0 & 248 \\
\hline Rototilling & 62 & 62 & 62 & 0 & 62 & 62 & 124 & 62 & 62 & 558 \\
\hline Harvesting & 0 & 247 & 0 & 0 & 0 & 0 & 247 & 0 & 0 & 495 \\
\hline Seed & 3 & 208 & 13 & 1 & 3 & 3 & 3 & 3 & 1 & 240 \\
\hline Transport van & 16 & 16 & 0 & 0 & 0 & 0 & 0 & 0 & 0 & 32 \\
\hline Fertilizer blend & 283 & 431 & 283 & 283 & 353 & 353 & 216 & 608 & 148 & 2958 \\
\hline Irrigation & 207 & 207 & 207 & 227 & 289 & 372 & 62 & 310 & 207 & 2088 \\
\hline Row cover & 0 & 0 & 0 & 0 & 0 & 0 & 0 & 604 & 0 & 604 \\
\hline Fertilizer broadcast & 24 & 24 & 24 & 24 & 0 & 0 & 24 & 24 & 0 & 146 \\
\hline Bone meal & 0 & 229 & 0 & 0 & 0 & 0 & 0 & 0 & 0 & 229 \\
\hline Mobile hoop house & 0 & 0 & 0 & 0 & 0 & 500 & 0 & 0 & 0 & 500 \\
\hline \multicolumn{11}{|l|}{ CF by area } \\
\hline$\left(\mathrm{kg} \mathrm{CO}_{2}\right.$-eq ha $\left.{ }^{-1} \mathrm{yr}^{-1}\right)$ & 1024 & 1943 & 980 & 967 & 1213 & 1699 & 1236 & 1764 & 589 & 11419 \\
\hline \multicolumn{11}{|l|}{ CF by yield } \\
\hline$\left(\mathrm{kg} \mathrm{CO}_{2}\right.$-eq kg fresh $\left.\mathrm{crop}^{-1}\right)$ & 0.053 & 0.033 & 0.360 & 0.058 & 0.035 & 0.042 & 0.046 & 0.102 & 0.050 & \\
\hline \multicolumn{11}{|l|}{ Expanded Boundary } \\
\hline Fencing & 98 & 98 & 98 & 98 & 98 & 98 & 98 & 98 & 98 & 883 \\
\hline Soil emission & 255 & 255 & 255 & 255 & 255 & 255 & 255 & 255 & 255 & 2295 \\
\hline Greenhouse & 192 & 0 & 0 & 0 & 192 & 192 & 192 & 192 & 0 & 959 \\
\hline
\end{tabular}




\begin{tabular}{|c|c|c|c|c|c|c|c|c|c|c|}
\hline Off-farm fuel & 365 & 365 & 365 & 365 & 365 & 365 & 365 & 365 & 0 & 2922 \\
\hline CF by area & 1934 & 2661 & 1698 & 1685 & 2123 & 2609 & 2146 & 2674 & 942 & 18472 \\
\hline \multicolumn{11}{|c|}{$\left(\mathrm{kg} \mathrm{CO}_{2}\right.$-eq ha $\left.{ }^{-1} \mathrm{yr}^{-1}\right)$} \\
\hline CF by yield & 0.101 & 0.045 & 0.623 & 0.101 & 0.062 & 0.065 & 0.079 & 0.155 & 0.080 & \\
\hline
\end{tabular}

( $\mathrm{kg} \mathrm{CO}_{2}$-eq kg fresh $\mathrm{crop}^{-1}$ ) 
Table 5. Soil $\mathbf{N}$ and $\mathbf{C}$ fluxes associated with the operation of the studied organic farm as estimated by CropSyst.

\begin{tabular}{lccc}
\hline Environmental feature & Value with & Value with only 1- & Value without \\
& cover crops & year cover crop & cover crops \\
\hline $\mathbf{N}$ flux & $\left(\mathrm{kg} \mathrm{N} \mathrm{ha}^{-1} \mathrm{yr}^{-1}\right)$ &
\end{tabular}

$\begin{array}{lccc}\mathrm{N} \text { leached below rooting zone } & 43 & 57 & 60 \\ \mathrm{~N}_{2} \mathrm{O} \text { emission } & 3.95 & 2.72 & 2.46\end{array}$

C flux

$\left(\mathrm{kg} \mathrm{Cha}{ }^{-1} \mathrm{yr}^{-1}\right)$

\begin{tabular}{llll}
\hline $0-5 \mathrm{~cm}$ soil C change $\dagger$ & -42 & 41 & 50 \\
$0-30 \mathrm{~cm}$ soil C change & 57 & 442 & 498 \\
Profile soil C change & 198 & 688 & 812 \\
$0-5 \mathrm{~cm}$ residue C change & 5 & 5 & 5 \\
$0-30 \mathrm{~cm}$ residue C change & -77 & -72 & -72 \\
Profile residue C change & -77 & -71 & -72 \\
$0-5 \mathrm{~cm}$ total C change & -37 & 46 & 55 \\
$0-30 \mathrm{~cm}$ total C change & -20 & 370 & 426 \\
Profile total C change & 121 & 617 & 740
\end{tabular}

Total GHG flux

$\left(\mathrm{kg} \mathrm{CO}_{2}\right.$-eq ha $\left.\mathrm{yr}^{-1}\right)$

$2293 \quad 3536 \quad 3865$

$\dagger$ Negative value indicates $\mathrm{C}$ decrease in atmosphere (gain in soil); positive value indicates $\mathrm{C}$ increase in atmosphere (loss from soil). 
Table 6. CropSyst estimates of yields using tabled harvest indices.

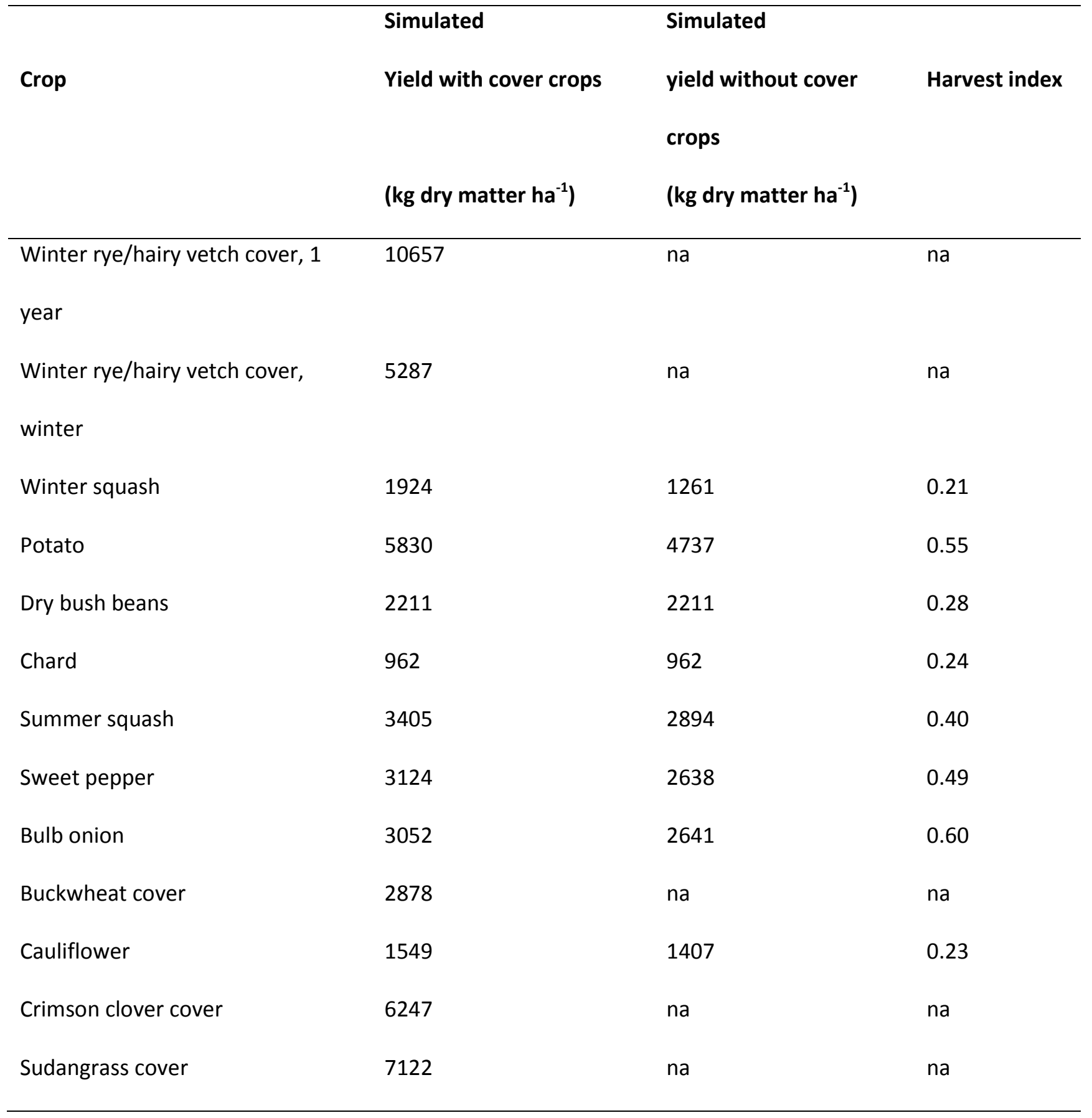




\section{Figures}

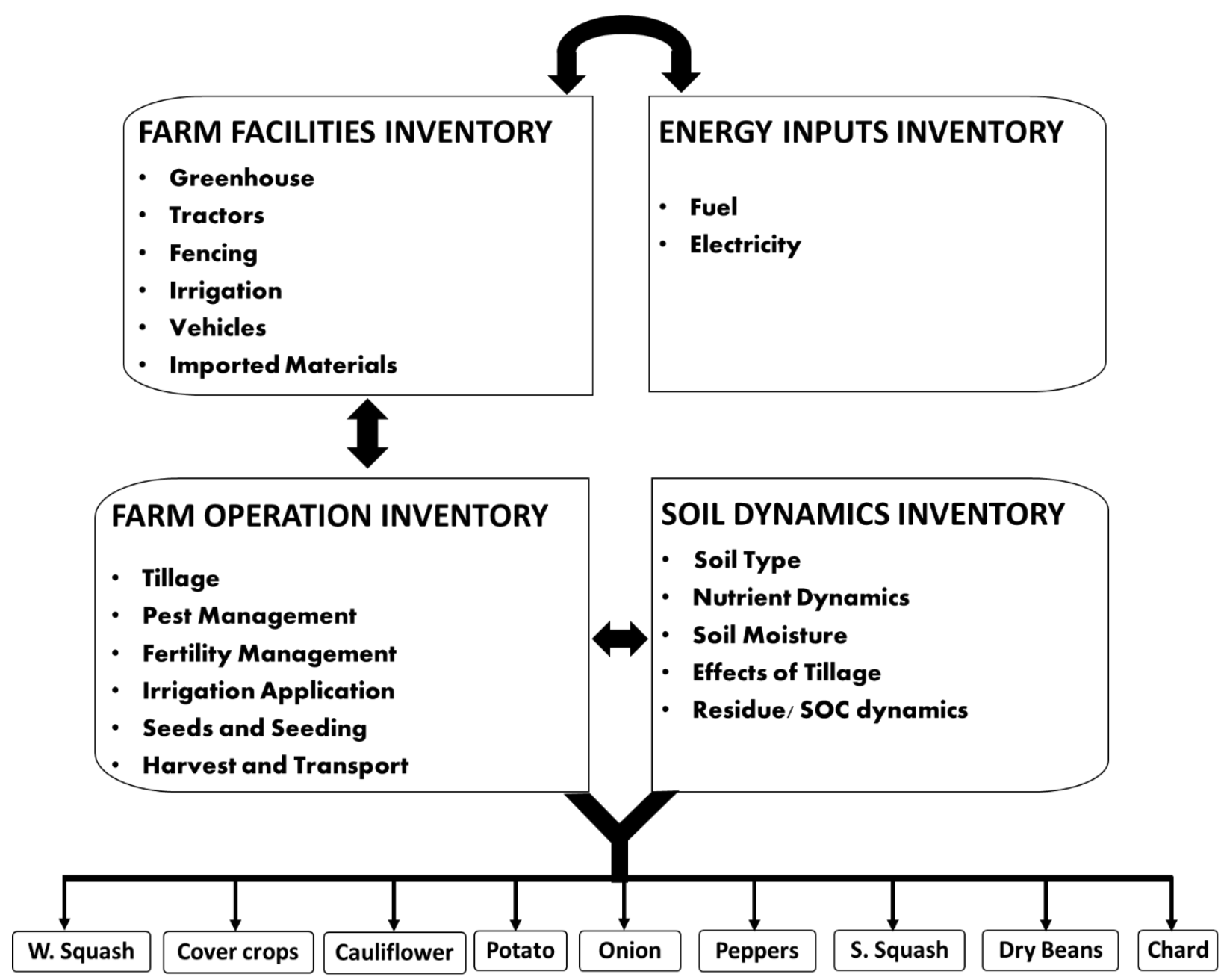

Fig 1. Flow diagram of the system boundaries and relevant inputs of an organic vegetable production system in western Washington State. 


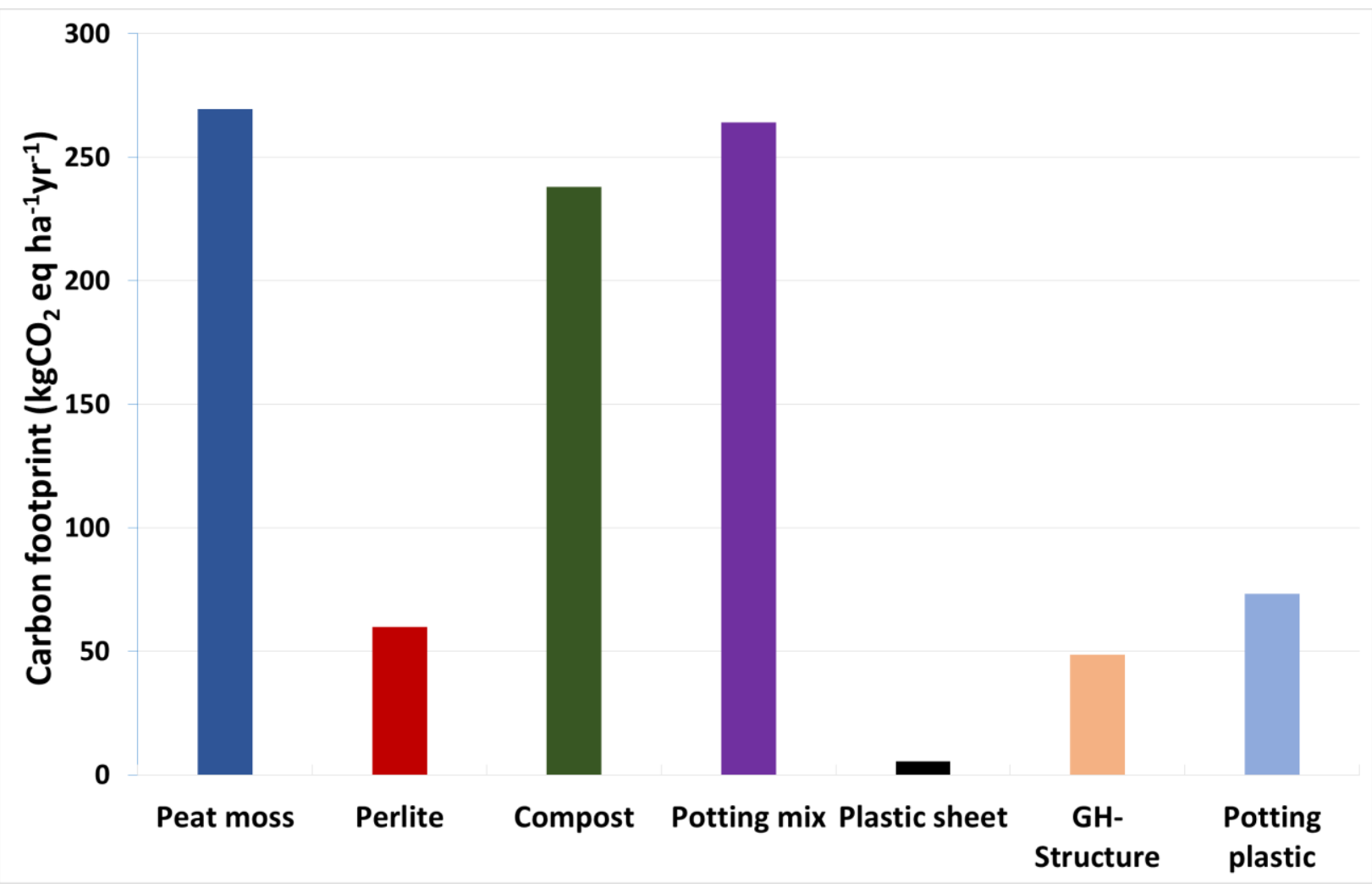

Fig 2. Contribution of various factors to the CF of greenhouse operations (unit) 


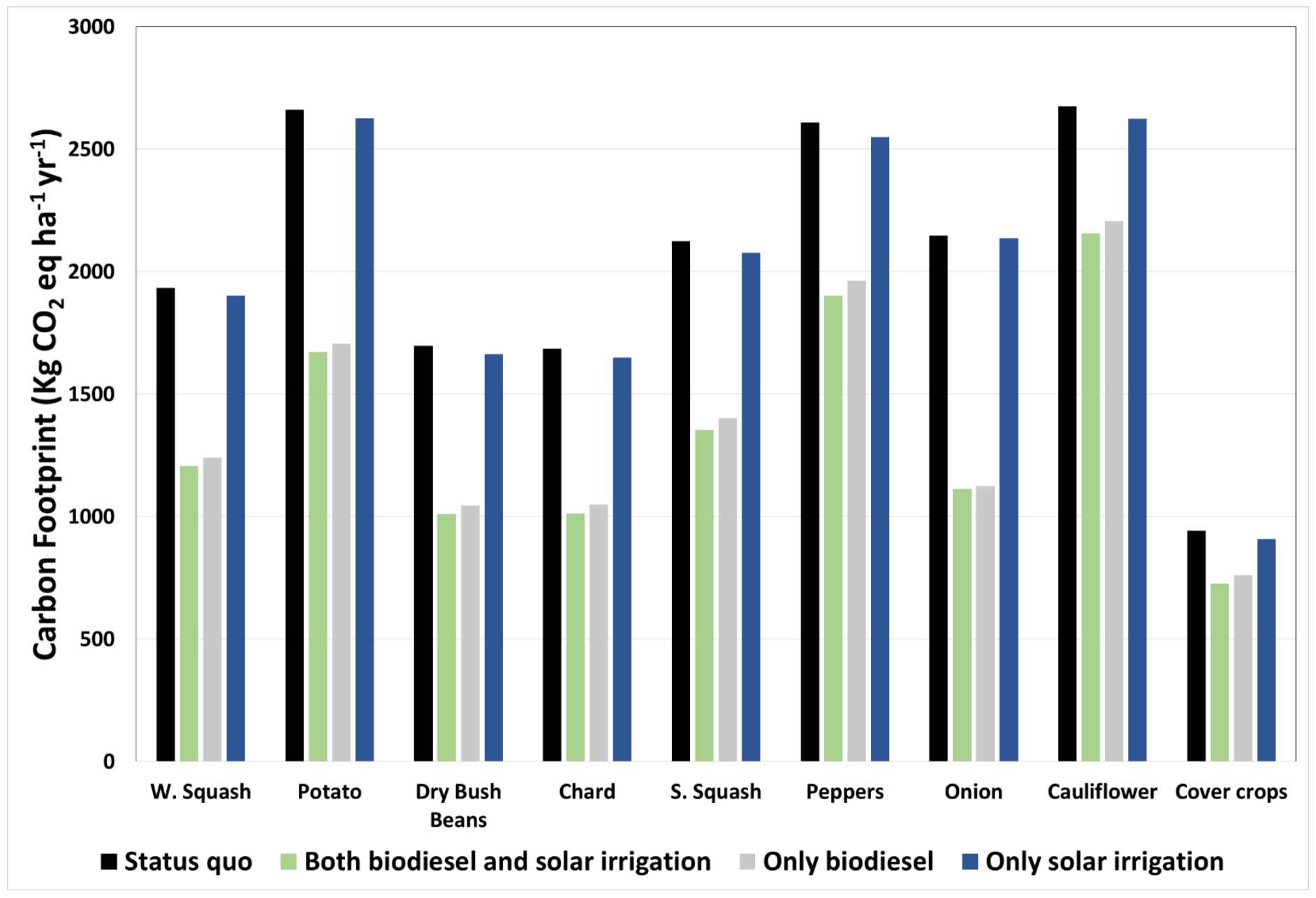

Fig 3. Carbon footprint of the farm's crops given the effect of a switch to the use of biodiesel and solar powered irrigation system. 


\section{Carbon footprint of inputs and operations in an}

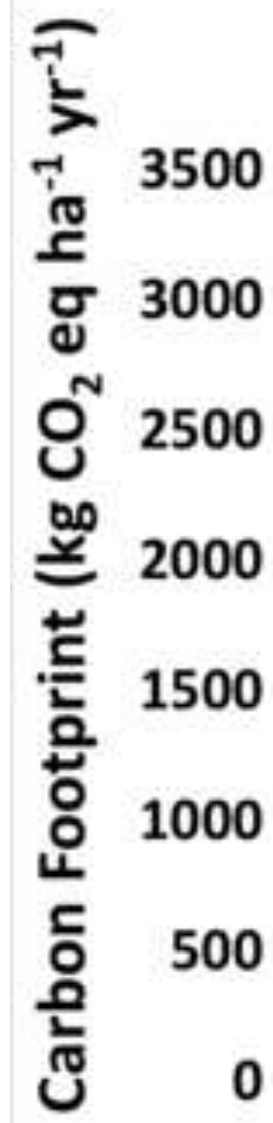

\section{organic vegetable farm}

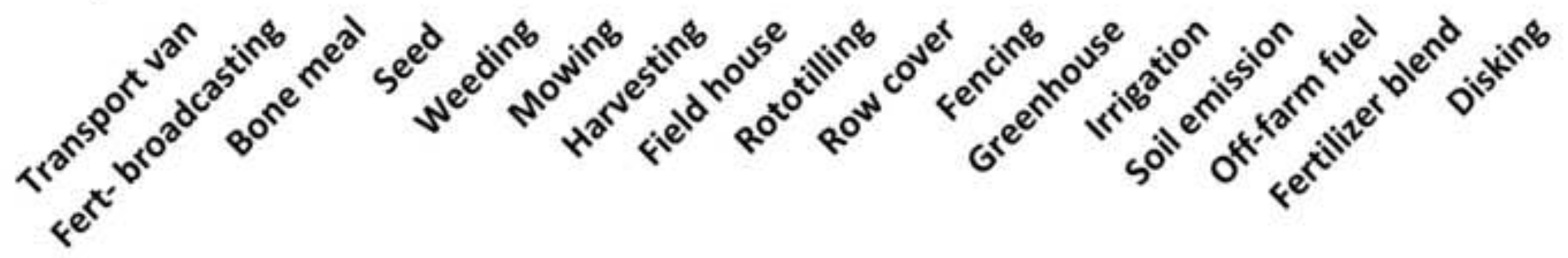

